\title{
Analisis Kewenangan Penyidik Kepolisian dan Badan Narkotika Nasional Dalam Penegakan Hukum Pidana Narkotika (Studi Kasus pada Polda Kepri dan Badan Narkotika Propinsi Kepulauan Riau)
}

\author{
Abdul Muchlis Hutabarat ${ }^{1 *}$ Idham $^{2}$, Henri Aspan ${ }^{3}$ \\ ${ }^{1}$ Department Master of Law, Faculty of Law, Batam University, Indonesia. \\ ${ }^{2}$ Department of Notary, Faculty of Law, Batam University, Indonesia. \\ Jalan UNIBA No. 5, Batam Center, Telp: 0778-7485055, Fax. 0778-7485054 \\ Email: zonahukum@univbatam.ac.id; lppm@univbatam.ac.id \\ *Correspondence email: abdulhutabarat@gmail.com; idhamnotppat@univbatam.ac.id
}

\begin{abstract}
Abstrak. Sampai dengan saat ini upaya untuk penanggulangan narkoba yang dilakukan oleh lembaga formal pemerintah (Dep.Kes, Imigrasi, Bea Cukai, POLRI, BNN, BNP, dan lain-lain) maupun oleh lembaga swadaya masyarakat lainnya masih belum optimal, kurang terpadu dan cenderung bertindak sendiri-sendiri secara sektoral. Masalah penyalahgunaan narkoba tidak tertangani secara maksimal, sehingga kasus penyalahgunaan narkoba cenderung meningkat baik secara kualitas dan kuantitas. Permasalahan dalam penelitian ini adalah Bagaimana Pengaturan Hukum Kewenangan Penyidikan Kepolisian Dan Badan Narkotika Nasional Terhadap Pidana Narkotika, Bagaimana Implementasi Kewenangan Penyidikan Kepolisian Dan Badan Narkotika Nasional Terhadap Pidana Narkotika, serta Faktor apa saja yang menjadi kendala, dan solusi Kewenangan Penyidikan Kepolisian Dan Badan Narkotika Nasional Terhadap Pidana Narkotika. Penelitian ini dilakukan guna mengetahui Pengaturan Hukum Kewenangan Penyidikan Kepolisian Dan Badan Narkotika Nasional Terhadap Pidana Narkotika, mengetahui Implementasi Kewenangan Penyidikan Kepolisian Dan Badan Narkotika Nasional Terhadap Pidana Narkotika, serta Faktor apa saja yang menjadi kendala, dan solusi Kewenangan Penyidikan Kepolisian Dan Badan Narkotika Nasional Terhadap Pidana Narkotika. Penelitian ini menggunakan metode deskriptif analitis dengan pendekatan yuridis sosiologis (sociologis legal research) untuk mengkaji peraturan perundang undangan yang berkaitan dengan proses penyelidikan dan penyidikan tidak pidana Narkoba. Hasil penelitian ini menunjukkan Kewenangan Penyidik Kepolisian Dan Badan Narkotika Nasional Dalam Penegakan Hukum Pidana Narkotika pada dasarnya sudah terlaksana sudah terlaksana dengan baik walaupun masih banyak kendala terutama benturan dalam perbedaan pelaksanaan undang - undang.
\end{abstract}

Kata Kunci: Kewenangan Penyidik; Kepolisian Dan Badan Narkotika Nasional; Penegakan Hukum Pidana Narkotika.

Abstract. Until now efforts to tackle drugs by formal government institutions (Ministry of Health, Immigration, Customs, Police, Narcotics Agency, etc.) as well as by other non-governmental organizations are still not optimal, are less integrated and tend to act individually sectorally. The problem of drug abuse is not handled optimally, so cases of drug abuse tend to increase both in quality and quantity.The problem in this research is how the Legal Arrangement of the Police and National Narcotics Agency Investigations Against Narcotics Criminals, How to Implement the National Police and Narcotics Agency Investigation Authority Against Narcotics Crimes, and what factors are obstacles, and the solution to the National Police and Narcotics Agency Criminal Investigation Authority Narcotics criminal. This research was conducted to determine the Legal Arrangement of the Police and National Narcotics Agency Investigation of Narcotics Criminals, the Implementation of the National Police and Narcotics Agency Criminal Investigation Authority Against Narcotics Criminal Acts, as well as what factors were constraints, and the solution of the National Narcotics and Police Narcotics Investigation Authority Against Criminal Crimes Narcotics. This study uses a descriptive analytical method with a sociological juridical approach (sociological legal research) to study the laws and regulations relating to the process of investigating and investigating non-criminal drugs. The results of this study indicate that the authority of the National Police and Narcotics Agency Investigators in Narcotics Criminal Law Enforcement has basically been implemented well, although there are still many obstacles, especially conflicts in the implementation of the law.

Keywords: Authority of Investigators; Police and National Narcotics Agency; Narcotics Criminal Law Enforcement

\section{PENDAHULUAN}

Penegak hukum adalah aparat yang melaksanakan proses upaya untuk tegaknya atau berfungsinya norma-norma hukum secara nyata sebagai pedoman perilaku dalam lalulintas atau hubungan-hubungan hukum dalam kehidupan bermasyarakat dan bernegara, untuk menjamin dan memastikan tegaknya hukum itu, apabila diperlukan, aparatur penegak hukum itu diperkenankan untuk menggunakan daya paksayang ditugaskan serta mengerti aturan hukum yang berlaku (UUD, UU,PP, PERPU, Kepres, Permen, Perda,dll) mereka mengerti akibatnya bila tidak dilaksanakan, ditaati dan diakui oleh masyarakat, penegak hukum bertugas melaksanakan kewajibannya untuk menegakkan hukum dan aturan pemerintah secara murni dan tegas, contoh lembaga penegak hukum antara lain Advokat, Kepolisian, Kejaksaan, KPK, BNN, Mahkamah Agung, dan Komisi Yudisial.

Sebenarnya lembaga penegak hukum tidak hanya terbatas pada lembaga-lembaga yang telah disebutkan sebelumnya (Kepolisian, KPK, BNN, Mahkamah Agung, Komisi Yudisial, Otoritas Jasa Keuangan, Badan Pengawas 
Pasar Modal, Direktorat Jenderal Imigrasi, Kejaksaan, serta Satpol PP). Lembaga-lembaga tersebut dapat dikatakan sebagai penegak hukum bukan hanya karena memiliki kewenangan terkait proses Peradilan, tetapi juga karena memiliki kewenangan menangkap, memeriksa, mengawasi, atau menjalankan perintah undang-undang di bidangnya masing-masing.

Berbagai macam kejahatan yang terjadi di zaman ini sangat beraneka ragam bentuknya mulai dari penipuan, penggelapan, bahkan sampai menghilangkan nyawa orang lain tidak segan-segan pelaku melakukannya demi uang sebagai alasan utamanya. Ketika seorang sudah menjadi tersangka di kepolisan kita sudah tentu berbicara masalah hukum acara pidana yang sudah berlaku di Indonesia berdasarkan Undang-Undang No. 8 tahun 1981 tentang Kitab Undang-Undang Hukum Acara Pidana (KUHAP). Makna dari tujuan Hukum Acara Pidana adalah mencari dan menemukan kebenaran materiil yang maksudnya kebenaran dan fakta-fakta atau kejadian-kejadian dengan tindak pidana

Tindak pidana penyalahgunaan narkotika bagi diri sendiri diatur dalam Pasal 127 Undang-Undang No. 35 Tahun 2009 tentang Narkotika, yang bunyinya:

(1) Setiap penyalahguna: a. Narkotika golongan I bagi diri sendiri dipidana dengan pidana penjara paling lama 4 (empat) tahun; b. Narkotika golongan II bagi diri sendiri dipidana dengan pidana penjara paling lama 2 (dua) tahun; dan, c. Narkotika golongan III bagi diri sendiri dipidana dengan pidana perjara paling lama 1 (satu) tahun.

(2) Dalam memutus perkara sebagaimana dimaksud pada ayat (1), hakim wajb memperhatikan ketentuan sebagaimana dimaksud dalam Pasal 54, Pasal 55, dan Pasal 103. (3) Dalam Penyalahguna sebagaimana dimaksud pada ayat (1), dapat dibuktikan atau terbukti sebagai korban penyalahgunaan, penyalah guna tersebut wajib menjalani rehabilitasi medis dan rehabilitasi sosial.

Sanksi pidana berupa pidana penjara yang dapat dijatuhkan Hakim. Hakim juga diberikan kemungkinan untuk tidak menjatuhkan pidana penjara, karena dalam pasal-pasal yang berkaitan dengan Pasal 127, terdapat pula kemungkinan penjatuhan sanksi tindakan rehabilitasi oleh Hakim.

Sampai dengan saat ini upaya untuk penanggulangan narkoba yang dilakukan oleh lembaga formal pemerintah (Dep.Kes, Imigrasi, Bea Cukai, POLRI, BNN, BNP, dan lain-lain) maupun oleh lembaga swadaya masyarakat lainnya masih belum optimal, kurang terpadu dan cenderung bertindak sendiri-sendiri secara sektoral. Masalah penyalah gunaan narkoba tidak tertangani secara maksimal, sehingga kasus penyalahgunaan narkoba makin hari bukannya semakin menurun tetapi cenderung meningkat baik secara kualitas dan kuantitas.

Salah satu unsur penegak hukum yang ada di Indonesia adalah Kepolisian Republik Indonesia (Kepolisian Republik Indonesia untuk selanjutnya disebut POLRI) selaku alat negara penegak hukum dituntut untuk mampu melaksanakan tugas penegakan hukum secara profesional dengan memutus jaringan sindikat dari luar negeri melalui kerjasama dengan instansi terkait dalam memberantas kejahatan penyalah gunaan narkoba, dimana pengungkap- an kasus narkoba bersifat khusus yang memerlukan proaktif dalam mencari dan menemukan pelakunya serta senantiasa berorientasi kepada tertangkapnya pelaku tindak pidana di bidang narkoba.

Efektifitas berlakunya Undang-Undang No. 35 Tahun 2009 tentang Narkotika sebagai pengganti UndangUndang No. 22 Tahun 1997 dan Undang-Undang No. 5 Tahun 1997 tentang Psikotropika sangatlah tergantung pada seluruh jajaran penegak hukum, dalam hal ini seluruh instansi yang terkait langsung yakni aparat Polri serta aparat penegak hukum lainnya.

\section{METODE}

\section{Pendekatan Penelitian}

Metode penelitian yang digunakan oleh penulis adalah menggunakan metode kualitatif, yakni penelitian mendalam dan menyeluruh (holistik) untukm memperoleh gambaran tentang Pengaturan Hukum Kewenangan Penyidikan Kepolisian Dan Badan Narkotika Nasional Terhadap Pidana Narkotika. Pendekatan Kualitatif menurut (Farouk Muhammad, 2003)

Penelitian kualitatif adalah penelitian eksploratif yang mempunyai proses yang dapat memberikan gambaran khusus terhadap suatu kasus secara mendalam. Sedangkan menurut Lincoln dan Guba (1985) dalam Lexy J Moleong (2001), bahwa penelitian kualitatif adalah penelitian yang dilakukan pada latar belakang alamiah atau pada konteks dari suatu keutuhan (entity), yang menghendaki adanya kenyataan-kenyataan sebagai keutuhan yang tidak dapat dipelajari apabila terpisah dari konteksnya.

\section{Sumber Data Dan Alat Pengumpulan Data}

Sumber data dalam penelitian ini adalah data primer dan data sekunder. Wawancara, yaitu penulis mengadakan tanya jawab dengan pihak-pihak yang terkait langsung denagan masalah yang dibahas, dalam hal ini adalah para penyidik Direktorat Narkoba Polretsa Barelang dan Badan Narkotika Nasional Propinsi Kepulauan Riau. Serta Studi dokumentasi, yaitu penulis mengambil data dengan mengamati dokumen-dokumen dan arsip-arsip yang terkait 
penelitian ini melalui studi dokumen tentang penanganan tindak pidana penyalahgunaan narkotika setelah diundangkannya Undang-Undang nomor 35 tahun 2009 tentang Narkotika yang ditangani Penyidik BNN dan Penyidik Polri.

Bahan hokum sekunder ini terdiri dari tulisan-tulisan yang tidak berbentuk peraturan perundang-undangan baik yang telah dipublikasikan maupun yang belum dipublikasikan. Bahan hukum sekunder ini diantaranya seperti hasil penelitian ahli hukum berupa buku atau literatur, hasil seminar, hasil simposium, hasil loka karya, diktat, skripsi dan juga artikelartikel serta jurnal hokum serta hasil wawancara dengan

1. Kabid Brantas BNNP Kepri

2. Humas BNNP Kepri

3. Dir Narkoba Polda Kepri

4. Kabid Humas Polda kepri

5. Annggota satuan Ditreskrim Polda Kepri

\section{Analisis Data}

Analisis data dalam penelitian ini menggunakan analisis kualitatif, artinya menguraikan data yang diolah secara rinci kedalam bentuk kalimat-kalimat (deskriptif). Analisis kualitatif yang dilakukan bertitik tolak dari analisis empiris, dalam pendalamannya dilengkapi dengan analisis normatif. Berdasarkan hasil analisis ditarik kesimpulan secara dedukatif, yaitu cara berpikir yang didasarkan pada fakta-fakta yang bersifat umum untuk kemudian ditarik suatu kesimpulan bersifat khusus

\section{HASIL DAN PEMBAHASAN}

Pengertian penyidik menurut Undang-Undang Nomor 8 tahun 1981 Tentang Kitab Undang-Undang Hukum Acara Pidana pada Pasal 1 butir (1) adalah pejabat polisi Negara Republik Indonesia atau Penyidik Pegawai Negeri Sipil tertentu yang diberi wewenang khusus oleh undang-undang untuk melakukan penyidikan. Dalam Ketentuan Umum Undang-Undang Nomor 2 tahun 2002 tentang Kepolisian Negara Republik Indonesia disebutkan bahwa penyidik adalah pejabat Kepolisian Negara Republik Indonesia yang diberi wewenang oleh Undang-undang untuk melakukan penyidikan, sedangkan yang berhak menjadi penyidik menurut Peraturan Pemerintah Republik Indonesia Tahun 1983 tentang pelaksanaan KUHAP adalah:

a. Pejabat Polisi Negara Republik Indonesia tertentu yang sekurang-kurangnya berpangkat Pembantu Letnan Dua Polisi.

b. Pejabat Pegawai Negeri Sipil tertentu yang sekurang-kurangnya berpangkat Pengatur Muda Tingkat I (Golongan II/b atau yang disamakan dengan itu).

Ketentuan di atas dengan pengecualian, jika disuatu tempat tidak ada pejabat penyidik sebagaimana dimaksud maka Komandan Sektor karena jabatannya adalah penyidik kepolisian berpangkat Bintara dibawah Pembantu Letnan Dua Polisi. Penyidik dari Polri yang berwenang melakukan penyidikan saat ini minimal harus seorang polisi dengan pangkat minimal Ajun Inspektur Polisi Dua (AIPDA), sedangkan untuk seorang polisi yang bertugas sebagai penyidik pembantu berasal dari Bintara polisi dengan pangkat minimal Brigadir Polisi Dua (BRIPDA), Brigadir Polisi Satu (BRIPTU), Brigadir atau Brigadir Kepala (BRIPKA).

Sesuai dengan KUHAP dan Undang-Undang Nomor 2 tahun 2002 tentang Kepolisian bahwa untuk meringankan beban penyidik juga telah diatur adanya penyidik pembantu. Penyidik pembantu adalah pejabat Kepolisian Negara Republik Indonesia yang diangkat oleh kepala Kepolisian Negara Republik Indonesia berdasarkan syarat kepangkatan yang diberi wewenang tertentu dalam melaksanakan tugas penyidikan yang diatur dalam undangundang.

Pejabat Penyidik Pembantu dalam KUHAP diatur dalam Pasal 10, selanjutnya Pasal 3 Peraturan Pemrintah Nomor 27 Tahun 1983 tentang Pelaksanaan KUHAP menetukan bahwa Penyidik Pembantu adalah Pejabat Polisi Negara Republik Indonesia yang berpangkat Sersan Dua Polisi dan Pejabat Pegawai Negeri Sipil tertentu dalam lingkungan Kepolisian Negara Republik Indonesia yang sekurang-kurangnya berpangkat Pengatur Muda atau yang disamakan dengan itu. Penyidik Pembantu tersebut diangkat oleh Kepala Kepolisian Republik Indonesia atas usul komandan atau pimpinan kesatuan masing-masing. Wewenang pengangkatan ini dapat dilimpahkan pada pejabat Kepolisian Negara yang lain.

Adanya makna penyelidikan hal ini disebabkan karena tidak semua peristiwa atau suatu perbuatan yang terjadi sebagai tindak pidana atau tidak semua tindak pidana itu jelas oleh karena perlu penyelidikan, untuk memastikan sebelum langkah selanjutnya, penyidikan dan upaya paksa (dwang middelen). Oleh karena itu sebelum melakukan penyidikan dengan konsekuensi didalamnya adanya upaya paksa, perlu ditentukan berdasarkan data atau keterangan 
Abdul Muchlis Hutabarat et al, Analisis Kewenangan Penyidik Kepolisian dan Badan Narkotika Nasional Dalam Penegakan Hukum Pidana Narkotika (Studi Kasus pada Polda Kepri dan Badan Narkotika Propinsi Kepulauan Riau)

yang didapat dari hasil penyelidikan bahwa peristiwa yang terjadi tersebut benar-benar merupakan tindak pidana dan dapat di lanjutkan dengan tindakan penyidikan.

\section{Pengaturan Hukum Kewenangan Penyidikan Kepolisian Dan Badan Narkotika Nasional Terhadap Pidana Narkotika}

Dari penelitian lapangan oleh peneliti didapati kewenangan penyidikan terkait batas waktu penangkapan yang dimiliki oleh Penyidik BNNP Kepri dan Penyidik Polda Kepri dengan menggunakan dasar hukum yang berbeda yaitu Penyidik BNNP Kepri menggunakan dasar penyidikan Pasal 75 Jo.Pasal 76 ayat (1) Undang-Undang No. 35 Tahun 2009 tentang Narkotika yang menyebutkan bahwa batas waktu penangkapan tindak pidana narotika adalh 3x24 jam. Sedangkan Penyidik Polrerta Barelang menggunakan KUHAP sebagai dasar hukum acaranya dalam hal batas waktu penangkapan yaitu $1 \times 24$ jam.

Hal ini menimbulkan implikasi yuridis dalam pelaksanaannya, yaitu terjadi dikarenakan penggunaan dasar hukum yang berbeda oleh Penyidik Polri dan Penyidik BNN yaitu dilihat dari perspektif yuridis yaitu terjadinya ketidak konsistenan, ketidaktegasan dan ketidakjelasan aparat penegak hukum dalam menggunakan dasar hukum yang dapat menimbulkan adanya suatu ketidakadilan dalam penerapan batas waktu penangkapan yang diterima oleh tersangka tindak pdana narkotika yang ditangani oleh BNN dan yang ditangani oleh Polri.

Penangkapan yang dilakukan oleh Polri dengan penggunaan dasar 1x24 jam kurang menjamin keakuratan data yang diperoleh dari laboraturium forensic untuk menjamin keterlibatan penyalahgunaan narkotika. Dengan penggunaan dasar hukum KUHAP yaitu 1x24 jam kurang memperhatikan ilmu kedokteran forensik dengan resiko jika Penyidik Polri tidak dapat menemukan alat bukti baru maka tersangka harus dilepaskan yang hal tersebut dapat berakibat penghlangan barang bukti atau tersangka dapat melarikan diri.

Dengan adanya perbedaan batas waktu penangkapan yang digunakan oleh BNN dan Polri yang mengakibatkan adanya implikasi yuridis, maka untuk adanya sinkronisasi atas perbedaan penggunaan dasar hukum tersebut yaitu dengan mengubah atau meniadakan pasal-pasal yang berkaitan dengan kewenangan penangkapan dengan memperhatikan asas-asas dalam perundang-undangan dan interpretasi hukum.

\section{Implementasi Hukum Kewenangan Penyidikan Kepolisian Dan Badan Narkotika Nasional Terhadap Pidana Narkotika.}

Penyidik tindak pidana narkotika berdasarkan Undang-Undang Nomor 35 Tahun 2009 Tentang Narkotika adalah penyidik Badan Narkotika Nasional, Penyidik Kepolisian Republik Indonesia. Kewenangan penyidikan masing-masing penyidik tersebut tidak memiliki perbedaan terkait obyek penyidikannya. UndangUndang tidak membagi tindak pidana narkotika dan prekursor narkotika yang mana yang ditangani penyidik Badan Narkotika Nasional, Penyidik Kepolisian Republik Indonesia. Hal ini berpotensi menimbulkan overlapping atau tumpang tindih dalam penyidikan perkara tindak pidana narkotika.

Kepolisian Republik Indonesia dan Badan Narkotika Nasional perlu pembagian kerja yang jelas, dengan tujuan agar masyarakat tidak bingung sekaligus menjadi pembeda terkait kualitas kinerja masing-masing pihak. Kedepan, keduanya perlu membuat diferensiasi apakah dalam bentuk kekhasan cara penangkapan, obyek tangkapan, spesialisasi narkoba yang disita dan sebagainya.

Adapun Pasal 81 Undang-Undang Nomor 35 Tahun 2009 Tentang Narkotika memberikan peluang untuk terjadinya tumpang tindih kewenangan diantara dua penegak hukum yaitu Badan Narkotika Nasional dan Kepolisian Republik Indonesia adapun bunyi Pasal tersebut sebagai berikut : Pasal 81 Penyidik Kepolisian Negara Republik Indonesia dan penyidik BNN berwenang melakukan penyidikan terhadap penyalahgunaan dan peredaran gelap Narkotika dan Prekursor Narkotika berdasarkan Undang-Undang ini.

Undang-Undang Nomor 35 Tahun 2009 Tentang Narkotika tidak memberikan batasan kewenangan penyidikan Badan Narkotika Nasional seperti Pasal 11 ayat (3) Undang-UndangNomor 30 Tahun 2002 tentang Komisi Pemberantasan Korupsi yang apabila kerugian RP. 1.000.000.000 (1 Milyar) ditangani oleh Komisi Pemberantasan Korupsi. Kedepan pemerintah dan dewan perwakilan rakyat harus memikirkan dan memberikan solusi terhadap tumpang tindihnya kewenangan antara Kepolisian Republik Indonesia dan Badan Narkotika Nasional. Yaitu dengan memperhatikan hal-hal sebagai berikut:

1. Tindak pidana dilakukan oleh pejabat penting dan berpengaruh

2. Mendapat perhatian yang meresahkan masyarakat luas.

3. Menyangkut $1 \mathrm{~kg} / 10$ ons jenis narkotikanya.

Oleh karena itu kewenangan yang dimiliki oleh Badan Narkotika Nasional harus memiliki batasan atau pembeda dengan kewenangan kepolisian. Akan tetapi paradigma dalam melakukan penyidikan terhadap tindak pidana narkotika harus mereka bangun guna mencapai tujuan dari sistem peradilan pidana 
Abdul Muchlis Hutabarat et al, Analisis Kewenangan Penyidik Kepolisian dan Badan Narkotika Nasional Dalam Penegakan Hukum Pidana Narkotika (Studi Kasus pada Polda Kepri dan Badan Narkotika Propinsi Kepulauan Riau)

\section{Faktor Yang Menjadi Kendala, Dan Solusi Kewenangan Penyidikan Kepolisian Dan Badan Narkotika Nasional Terhadap Pidana Narkotika.}

Kewenangan Penyidikan Kepolisian Republik Indonesia Berdasarkan Undang undang Nomor 35 Tahun 2009

Tentang Narkotika memberikan kewenangan kepada Kepolisian Republik Indonesia Pasal 81 yang berbunyi: Penyidik Kepolisian Republik Indonesia dan penyidik Badan Narkotika Nasional berwenang melakukan penyidikan terhadap penyalahguna dan peredaran gelap narkotika dan prekursor narkotika berdasarkan Undang-undang ini. Kewenangan penyidikan Badan Narkotika Nasional dengan Kepolisian Republik Indonesia, apabila dikaji dari perspektif sistem peradilan pidana yakni sebagai kesatuan sistem yang integral, dimana pembagian kewenangan penyidikan harus jelas tidak terjadi tumpang tindih, namun meskipun masing-masing komponen sub-sistem memiliki fungsi dan kewenangan yang berbeda tetapi dalam konsep sistem peradilan pidana masingmasing sub-sistem harus mempunyai persepsi, sikap dan tujuan yang sama. Penyidik tindak pidana narkotika berdasarkan Undang-undang Nomor 35 Tahun 2009 Tentang Narkotika adalah penyidik Badan Narkotika Nasional dan Penyidik Kepolisian Republik Indonesia.

Kewenangan penyidikan masing-masing penyidik tersebut tidak memiliki perbedaan terkait obyek penyidikannya. Undang-undang tidak membagi tindak pidana narkotika dan prekursor narkotika yang mana yang ditangani penyidik Badan Narkotika Nasional dan Penyidik Kepolisian Republik Indonesia. Hal ini berpotensi menimbulkan overlapping atau tumpang tindih dalam penyidikan perkara tindak pidana narkotika. Penyidik tindak pidana narkotika berwenang dalam mengungkap penyalahgunaan dan peredaran gelap narkotika tentunya akan berdampak baik dalam pemberantasan tindak pidana narkotika yang semakin kecenderungan yang semakin meningkat baik secara kuantitatif maupun kualitatif dengan korban yang meluas, terutama di kalangan anak-anak, remaja, dan generasi muda pada umumnya.

Walaupun demikian di sisi lain, bukan tidak mungkin akan menimbulkan dualisme dalam penyelesaian tindak pidana narkotika karena masing-masing penyidik merasa berhak melakukan penyidikan yang bukan tidak mungkin pada akhirnya akan merugikan ataupun menghambat proses pemberantasan penyalahgunaan dan peredaran gelap narkotika. Sebagai akibat adanya dualisme tersebut bukan tidak mungkin terjadi tumpang tindih (overlapping) serta saling berebut kekuasaan.

Hal ini tidak terlepas dari perebutan prestasi masing-masing Penyidik karena tindak pidana narkotika memiliki nilai yang cukup strategis baik dalam rangka penitian karier atau terkait dengan tingginya nilai ekonomi penyalahgunaan dan peredaran gelap narkotika. Oleh karena itu, harus dibuat mekanisme yang efektif dan efisien, sehingga persaingan yang tidak sehat dapat ditekan seminimal mungkin. Mekanisme kerjasama antara penyidik Badan Narkotika Nasional dan penyidik Kepolisian Republik Indonesia atau dengan penyidik lainnya, sudah diatur dalam Undang-undang Nomor 35 Tahun 2009 Tentang Narkotika.

Dalam melakukan penyidikan terhadap penyalahgunaan dan peredaran gelap Narkotika penyidik Kepolisian Republik Indonesia memberitahukan secara tertulis dimulainya penyidikan kepada penyidik Badan Narkotika Nasional begitu pula sebaliknya. Sementara itu, dalam melakukan penyidikan terhadap penyalahgunaan narkotika penyidik pegawai negeri sipil tertentu berkoordinasi dengan penyidik Badan Narkotika Nasional atau penyidik Kepolisian Republik Indonesia sesuai dengan Undang-undang tentang hukum acara pidana.

Ketentuan tersebut mengisyaratkan bahwa langkah kerjasama untuk menghindarkan penyalahgunaan wewenang atau penyerobotan wewenang oleh salah satu pihak ke pihak yang lain, khususnya antara penyidik Kepolisian Republik Indonesia dengan penyidik Badan Narkotika Nasional. Sedangkan untuk penyidik pegawai negeri sipil, segala upayapenyidikan diarahkan untuk membantu dan menyerahkan hasilnya kepada penyidik Kepolisian Republik Indonesia maupun penyidik Badan Narkotika Nasional.

Dalam tahap penyidikan permasalahan tumpang tindih dapat dihindari karena kewajiban saling memberitahukan secara tertulis dimulainya penyidikan, tetapi dalam tahap penyelidikan karena sifatnya tertutup dan tidak ada kewajiban saling memberitahukan maka bukan tidak mungkin ada kesamaan target operasi antara intel Badan Narkotika Nasional dan intel Kepolisian Republik Indonesia. Sejauh ini di tingkat pimpinan tidak ada permasalahan berarti dikarenakan koordinasi yang erat antar pimpinan Badan Narkotika Nasional dan Kepolisian Republik Indonesia, tetapi di lapangan pernah terjadi antara Badan Narkotika Nasional dan Kepolisian Republik Indonesia memiliki target operasi yang sama dan dalam situasi ini system yang digunakan siapa cepat dia yang dapat. Kondisi seperti di atas apabila dibiarkan terus terjadi dapat menimbulkan pergesekan antara kedua lembaga penyidik tindak pidana narkotika tersebut mengingat Badan Narkotika Nasional juga membentuk badan narkotika propinsi di tingkat propinsi dan Badan Narkotika Kota di tingkat kabupaten yang akan juga melakukan penyelidikan dan penyidikan di wilayah masing-masing.

Selain itu keberadaan Badan-Badan Narkotika tersebut akan menghamburkan anggaran karena masing-masing penyidik akan mengeluarkan biaya dalam kegiatan intelijen pengungkapan kasus tersebut tetapi apabila tanpa koordinasi yang jelas bisa jadi masing-masing memiliki target operasi yang sama. Tetapi berbeda apabila terdapat 
tersangka dari kasus yang ditangani penyidik Kepolisian Republik Indonesia merupakan bagian dari jaringan yang sama dengan tersangka yang sedang ditangani penyidik Badan Narkotika Nasional dengan koordinasi yang baik masing-masing lembaga dapat saling bantu-membantu informasi dalam membongkar suatu jaringan

\section{SIMPULAN}

1. Pengaturan Hukum Kewenangan Penyidikan Kepolisian Dan Badan Narkotika Nasional Terhadap Pidana Narkotika adalah: BNN secara tegas diberikan kewenangan oleh Pasal 75 huruf $(\mathrm{g})$ jo. Pasal 76 Undang-Undang Nomor 35 Tahun 2009. BNN diberikan waktu penangkapan paling lama 3 x 24 jam dan dapat diperpanjang paling lama 3 x 24 jam. Sedangkan dalam kewenangan penyidik Polri yang tertuang dalam Pasal 16 jo. Pasal 19 UndangUndang Nomor 8 Tahun 1981 Tentang Hukum Acara Pidana yaitu penangkapan dilakukan paling lama satu hari. Hal ini menjadi perhatian manakala tersangka tindak pidana narkotika sedang menjalani penyidikan akan menerima perbedaan perlakuan menurut perhitungan waktu penangkapan. Perbedaan kewenangan terkait dengan batas waktu penangkapan tersebut, menjadi suatu pertanyaan akan perbedaan penggunaan dasar hukum yang digunakan oleh Penyidik BNN dan Penyidik Kepolisian Negara Republik Indonesia dalam menyelesaiakan suatu tindak pidana narkotika. Mengingat, Undang-Undang Nomor 35 Tahun 2009 Tentang Narkotika adalah Lex specialis dari Kitab Undang-undang Hukum Acara Pidana yaitu penyalahgunaan narkotika merupakan suatu tindak pidana khusus yang pengaturannya dipisahkan dari KUHAP.Akibat dari adanya perbedaan dasar hukum yang digunakan oleh Penyidik Polri dan Penyidik BNN tersebut mengakibatkan adanya suatu implikasi yuridis terhadap terjadinya perbedaan penngaturan penangkapan terhadap pelaku tindak pidana Narkotika oleh Penyidik BNN dan Penyidik Polri Tindak pidana narkotika yang diatur dalam Undang-undang Narkotika berlaku dengan mempertimbangkan aspek yuridis, folosofis dan sosiologis.. Dalam Undang-undang Narkotika yang mengatur mengenai suatu"Extra Ordinary Crime"dengan macam modus operandi, aparat penegak dan sanksinya banyak memiliki implikasi dalam menegakan apa yang tertulis dalam UndangUndang narkotika. Implikasi yang terjadi dalam Undang-Undang Narkotika dapat terlihat yaitu: Terjadinya Perbedaan Penafsiran Dalam Pelaksanaannya yaitu, Kepolisian Republik Indonesia kurang memperhatikan keberadaan dari pasal 81 yang mengatur mengenai kewenangan Penyidik Kepolisian yang juga diatur dalam Undang-undang Narkotika. Timbulnya Ketidak Pastian Hukum Kedua lembaga yang berwenang melakukan penyidikan terhadap penyalahgunaan dan peredaran gelap narkotika yaitu BNN dan Kepolisian Negara Republik Indonesia menggunakan dasar hukum batas waktupenangkapan yang berbeda. Adanya ketidak konsistennya dari aparat penegak hokum untuk menegakkan hukum sesuai dengan perundangundangan yang berlaku baik dari BNN ataupun Polri; Adanya ketidaktegasan dari aparat penegak hukum untuk menentukan penggunaan dasar hukum sebagai aturan pelaksaan dari suatu hukum; Adanya ketidakjelasan dari para penegak hukum untuk memberikan keadilan bagi tersangka tindak pidana narkotika. Penangkapan yang dilakukan oleh Polri dengan menggunakan dasar hukum KUHAP yaitu 1x24 jam belum dapat menjamin keakuratan data. Sedangkan BNN dengan menggunakan dasar hokum Undang-Undang

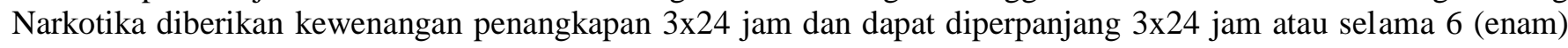
hari didasarkan pada pentingnya keakuratan data yang ditunjang oleh hasil pengujian sample pada laboraturium forensik. Dalam hal ini penyidik Kepolisian dengan menggunakan dasar hukum pada KUHAP menggunakan waktu penangkapan yaitu 1x24 jam kurang memperhatikan peran ilmu kedokteran forensik atau kriminalistik dimana kedua bidang tersebut dapat secara akurat membuktikan ada tidaknya kandungan zat-zat berbahaya dalam pelaku tindak pidana narkotika. Kepolisian Republik Indonesia menggunakan dasar hokum KUHAP dalam pelaksaan tugas dan kewenangannya, yang dalam hal ini adalah mengenai penangkapan terhadap pelaku tindak pidana narkotika menyebutkan bahwa penangkapan dilakukan untuk paling lama satu hari.Dalam hal ini, juga ditemukan adanya sudut pandang positif dan negatif dari pemberlakuan dasar hukum batas waktu penangkapan yang berbeda oleh Polri dan BNN. Sudut pandang negatif penggunaan dasar KUHAP yaitu 1x24 jam adalah tersangka yang harus dilepaskan dapat menghilangkan barang bukti lain yang dapat menunjang keakuratan pengumpulan alat bukti. Dikaji dari sudut pandang positif KUHAP memberlakukan asas Praduga tak bersalah sebagai upaya untuk menjamin Hak Asasi Manusia

2. Implementasi Kewenangan Penyidikan Kepolisian Dan Badan Narkotika Nasional Terhadap Pidana Narkotika Penyidik BNN, penyidik Polri dan PPNS menurut peraturan yang mengatur kewenangannya, disebutkan saling berkordinasi, utamanya penyidik BNN dengan penyidik Polri, dan antara PPNS dengan penyidik Polri. Namun koordinasi, perlu dipikirkan kelemahannya yang barangkali tidak terjangkau ketika merumuskan Undang-undang. Disinilah sebenarnya sering terjadi gesekan, hambatan ataukah konflik antar instansi penegak hukum, dimana para instasi ini merasa memiliki hak yang sama.

3. Kendala, dan solusi Kewenangan Penyidikan Kepolisian Dan Badan Narkotika Nasional Terhadap Pidana Narkotika Penangkapan yang dialkukan dengan penggunaan dasar 1 x 24 (satu kali dua puluh empat) jam kurang menjamin keakuratan data yang diperoleh dari laboratorium forensik untuk menjamin keterlibatan penyalahgunaan 
narkotika. Dengan menggunakan dasar hukum KUHAP yaitu 1 x 24 ( satu kali dua puluh empat ) jam kurang memperhatikan ilmu kedokteran forensic dengan resiko jika penyidik Bareskrim tidak dapat menemukan alat bukti baru maka tersangka harus dilepaskan yang hal tersebut dapat berakibat penghilangan barang bukti atau tersangka dapat melarikan diri. Tumpang Tindih (Overlapping) Dalam Hal Kewenangan Penyidikan Kepolisian Republik Indonesia Berdasarkan Undang undang Nomor 35 Tahun 2009 Tentang Narkotika memberikan kewenangan kepada Kepolisian Republik Indonesia Pasal 81. Serta Keterbatasan Personil, Saksi Penangkapan, Kurangnya jumlah peralatan yang diperlukan, Terbatasnya Biaya Operasional.

\section{DAFTAR PUSTAKA}

\section{Buku}

Afrizal. 2016. Metode Penelitian Kualitatif: Sebuah upaya Mendukung Pengguanaan Penelitian Kualitatif dalam Berbagai Disiplin Ilmu. Jakarta: PT. Raja Grafindo Persada, Jakarta.

AR. Sujono dan Bony Daniel, Tarmizi (Ed). 2011. Komentar dan Pembahasan Undang-Undang Nomor 35 Tahun 2009 Tentang Narkotika. Sinar Grafika. Jakarta Timur.

Adami Chazawi. 2002. Pelajaran Hukum Pidana bagian I. Raja Grafindo Persada. Jakarta.

Badan Narkotika Nasional. 2019. Komunikasi Penyuluhan Pencegahan Penyalahgunaan Narkoba. Jakarta. Halaman 7.

Bakhri, Syaiful, 2012. Kejahatan Narkotika dan psikotropika, Gramata publishing, Jakarta hal 3.

Bambang Sunggono, 2008 Metode Penelitian Hukum, (Jakarta:Raja grafindo persada,), hlm 39.

Barda Nawawi Arief, 2005 Beberapa Aspek Kebijakan Penegakan dan Pengembakan Hukum Pidana, Bandung, Citra Aditya Bakti, , hal.39-40.

Heriadi Willy, S.H., 2015. Berantas Narkoba Tak Cukup Hanya Bicara. UII Press: Yogyakarta.

Harahap, Yahya. Pembahasan Permasalahan dan Penerapan KUHAP Penyidikan dan Penuntutan, Sinar Grafika, Jakarta, 2012, halaman 18

Humas Badan Narkotika Nasional Propinsi Kepri 2020.

Humas Polda Kepri 2020.

Indonesia, Undang-Undang tentang Narkotika, UU No.35 tahun 2009, LN No. 143 tahun 2009, TLN No.5062, Pasal 1 butir 1 dan 2.

Kurniawaty Rosalita Yuliana, 2015 Problematika Penetapan dan Penangkapan Tersangka. Bhineka : Jakarta. Hal 4

Kusno Adi. 2009.Kebijakan Kriminal Dalam Penanggulangan Tindak Pidana Narkotika Oleh Anak, UMM Press. Malang.

Lawrence M.Friedman, 2011 American Law: an Introduction, Second Edition, New York: W.W Norton and Company, 1984, hal.5-6.MahrusAli,. Dasar-Dasar Hukum Pidana. Sinar Grafika. Jakarta.hlm 8

Makaro, Taufik. Tindak Pidana Narkotika, Bogor: Ghalia Indonesia, 2015 halaman 27

Marpaung, Laden. Proses Penanganan Perkara Pidana ( penyelidikan dan penyidikan), Sinar Grafika, Jakarta, 2011, halaman 31

Mulyadi, Lilik. Hukum Acara Pidana Normatif, Teoritis, Praktik dan Permasalahanya, P.T Alumni, Bandung, 2012 Halaman 20

Mardjono Reksodiputro, 2007 Hak Asasi Manusia Dalam Sistem Peradilan Pidana, Jakarta, Pusat Pelayanan Keadilan dan Pengabdian Hukum Universitas Indonesia, , hal.93

Mardjono Reksodiputro, 2007 Sistem Peradilan Pidana Indonesia (Melihat Kejahatan dan Penegakan Hukum Dalam Batas-Batas Toleransi), Bunga Rampai Permasalahan dalam Sistem Peradilan Pidana, Jakarta, Pusat Pelayanan Keadilan dan Pengabdian Hukum Universitas Indonesia, , hal.6.

Mardjono Reksodiputro 2009, Selayang Pandang Pemikiran Tentang Kriminologi, Makalah yang disampaikan dalam rangka studium Geneale di Dep.Kriminologi Fisip UI, 2009, 8 September hal.14.

Mardjono Reksodiputro 2007, Kriminologi dan Sistem Peradilan Pidana, Kumpulan Karangan Buku Kedua, Jakarta, Pusat Pelayanan Keadilan dan Pengabdian Hukum, , hal.141-142.

Muladi, 2004, Kapita Selekta Sistem Peradilan Pidana, Semarang, Universitas Diponegoro, , hal 1-2.

Mulyadi, Lilik. Hukum Acara Pidana Normatif, Teoritis, Praktik dan Permasalahanya, P.T Alumni, Bandung, 2012 Halaman 20

M. Taufik Makarao, et.al., 2003. Tindak Pidana Narkotika. Ghalia Indonesia. Jakarta. Halaman 27

M. Yahya Harahap, S.H. 2016, Pembahasan Permasalahn Dan Penerapan KUHAP Penyidikan Dan Penuntutan. Sinar Grafika halaman 15.

Nazir, Moh., Ph.D, 2009, Metode Penelitian, Bogor: Ghimia Indonesia,. Hal. 23.

Soerjono Soekanto, Pengantar Penelitian Hukum, (Jakarta:Universitas Indonesia, 2012), hlm 42.

Soerjono Soekanto, Pengantar Penelitian Hukum, (Jakarta:Universitas Indonesia, 2012), hlm 42. 
Soedjono Dirdjosisworo. 2016. Segi Hukum tentang Narkotika di Indonesia. Karya Nusantara. Bandung.

Suparmono, G, Hukum Narkotika Indonesia, djambatan, jakarta. .2011 halaman 13.

Suharsil, Tindak Pidana Narkotika, Bogor : Ghalia Indonesia, 2015 halaman 20

Suharsimi Arikunto, Prosedur Penelitiaan Suatu Pendekatan Praktek, Jakarta, Rineka Cipta. 2012, Hal. 22.

Sugiyono, Metode Penelitian Manajemen, Bandung, Alfabeta, 2014, Hal. 384.

TriAndrisman, 2009.Hukum Pidana : Asas Asas dan Dasar Aturan Umum Hukum Pidana Indonesia. Lampung.Penerbit Universitas Lampung. hlm 12

Yahya Harahap, Pembahasan Permasalahan dan Penerapan KUHAP, Penyidikan dan Penuntutan, Jakarta, Sinar Grafika cet.10, 2000, hal.90.

\section{Peraturan Perundang-Undangan}

Indonesia, Undang-Undang Tentang Narkotika, UU Nomor 9 Tahun 1976, LN No.37 Tahun 1976, TLN No.3086. , Undang-Undang Tentang Hukum Acara Pidana, UU Nomor 8 Tahun 1981, LN No. 76 Tahun 1981, TLN No.3209. 3698. , Undang-Undang Tentang Narkotika, UU Nomor 22 Tahun 1997, LN No 67 Tahun 1997, TLN No. , Undang-Undang tentang Komisi Pemberantasan Korupsi, UU Nomor 30 Tahun 2002, LN No.137 tahun 2002, TLN No.4250

$$
\text { Undang-Undang Tentang Narkotika, UU Nomor } 35 \text { Tahun }
$$
2009, LN No 143 tahun 2009, TLN No. 5062.

Peraturan Presiden Nomor 23 Tahun 2010 Tentang Badan

Narkotika Nasional.

Peraturan Kepala BNN Nomor : Per/03/V/2020/BNNP/KEPRI tanggal 12 Mei 2020 Tentang Organisasi dan Tata Kerja BNN.

Surat Edaran Mahkamah Agung Nomor 4 Tahun 2010 tanggal 7 April 2010 tentang Penempatan Penyalahgunaan, Korban Penyalahgunaan Dan Pecandu Narkotika Ke Dalam Lembaga Rehabilitasi Medis Dan Rehabilitasi Sosial.

\section{Buku Pedoman Thesis, Makalah, Artikel, Jurnal dan Surat Kabar}

Buku PedomaN Penyusunan Proposal dan Thesis Program Magister Ilmu Hukum Pasca Sarjana (S2), Universitas Batam, 2020.

\section{Website/Internet}

https://bnn.go.id/ diakses pada tanggal 6 maret 2020. 